\title{
Cultivation of Aquatic Plants for Biofiltration of Wastewater
}

\author{
Gasim Hayder 1,2 (D), Hauwa Mohammed Mustafa $3,4, *$ (D) \\ 1 Institute of Energy Infrastructure (IEI), Universiti Tenaga Nasional (UNITEN), 43000 Kajang, Selangor Darul Ehsan, \\ Malaysia; gasim@uniten.edu.my (G.H.); \\ 2 Department of Civil Engineering, College of Engineering, Universiti Tenaga Nasional (UNITEN), 43000 Kajang, Selangor \\ Darul Ehsan, Malaysia; \\ 3 College of Graduate Studies, Universiti Tenaga Nasional (UNITEN), 43000 Kajang, Selangor Darul Ehsan, Malaysia \\ hauwa.mustafa@uniten.edu.my (H.M.M.); \\ 4 Department of Chemistry, Kaduna State University (KASU), Tafawa Balewa Way, P.M.B. 2339, Kaduna, Nigeria \\ * Correspondence: hauwa.mustafa@ uniten.edu.my;
}

Scopus Author ID 56239664100

Received: 25.08.2020; Revised: 27.09.2020; Accepted: 29.09.2020; Published: 3.10.2020

\begin{abstract}
Efficient wastewater management has a vital role in monitoring the flood for hazard mitigation and also peoples' well-being through the hindrance of virus infection. Wastewater is generally produced through the household activities, farming works, and manufacturing process. Wastewater must be treated before discharge into the natural water sources or pollute the water supply. In this research study, aquatic plants were used for the biofiltration of treated domestic wastewater before discharge into the environment. The results obtained from the study demonstrated that the $\mathrm{pH}$ has no significant change (or even marginally). The $\mathrm{pH}$ of the wastewater sample was classified as safe before the treatment. However, the reduction of turbidity, nitrate, phosphorous, and ammonia using the biofiltration techniques yielded positive results. Therefore, biofiltration is an excellent alternative to tertiary wastewater treatment.
\end{abstract}

Keywords: $\mathrm{pH}$; nitrate; ammonia; giant Salvinia; water lettuce; water hyacinth.

(C) 2020 by the authors. This article is an open-access article distributed under the terms and conditions of the Creative Commons Attribution (CC BY) license (https://creativecommons.org/licenses/by/4.0/).

\section{Introduction}

Efficient wastewater management has a vital role in monitoring the flood for hazard mitigation and the well-being of people. Wastewater is generally produced through household activities, farming works, and manufacturing processes. Wastewater must be treated prior to discharge to the natural water sources, or it will pollute the water supply. Wastewater must be conveyed to the wastewater treatment plant to be treated, and it has to be conveyed through the drainage systems. Drainage systems consist of a complex substructure such as pipes, pumps, screens, and channels [1]. Some countries in the world, mainly Latin American countries, depending on water exports, which currently is rising around 3.5 times at the rate of exports. These make Mexico as the most significant contributor to water exports in Latin America. The demand is increasingly high and is projected to continue in the coming years, which can lead to water shortages if left unmitigated [2]. Furthermore, the use of macrophytes in the biofiltration process of wastewater is more effective in areas with warm climates. However, it appears to be an ideal option for developed nations because of the benefits of this purification process [3]. Numerous studies have shown that macrophytes have the capacity to absorb excess 
nutrients from wastewater [4]. Pavithra and Kousar [5] evaluated the potentials of giant Salvinia in the treatment of textile wastewater. The outcome of the study indicated that giant Salvinia is effective in the treatment of textile wastewater. Hanafiah et al. [6] investigated the potentials of phytoremediation using $P$. stratiotes and $S$. molesta in the treatment of wastewater. The study indicated that $P$. stratiotes and $S$. molesta are efficient in the removal of total suspended solids and ammoniacal nitrogen. Ariffin et al. [7] studied the efficiency of Azolla pinnata for phytoremediation of wastewater aquaculture. The result obtained indicated that Azolla pinnata drastically reduced the ammonia and phosphate content in the aquaculture wastewater.

In this study, three well-known plants that are widely known to be used for biofiltration of water treatment were used. The plants that we used are Water Lettuce, Water Hyacinth, and Giant Salvinia. The plants were locally sourced and installed into the acrylic tank. All the selected vegetation used are well known for its chemical treatment properties and sediment filtering. Among the most common water treatment vegetation is water lettuce, or Pistia stratiotes. Water Lettuce is reported to yield a good result in filtering and treating municipal wastewater [8]. Additionally, the vegetation is responsible for being a hyperaccumulator of trace metals such as $\mathrm{Cr}, \mathrm{Cu}, \mathrm{Fe}, \mathrm{Mn}, \mathrm{Ni}, \mathrm{Pb}$, and also $\mathrm{Zn}$, referring to the vegetation bioconcentration factor index [9]. Pistia stratiotes is a common plant that can be found worldwide due to its climate tolerance, and it naturally grows well within a temperature range of $15-35{ }^{\circ} \mathrm{C}$ [10].

The roots of water hyacinth (WH) naturally absorb pollutants as well as some organic compounds which are carcinogenic and have dilution in a region of 10,000 times that is usually found in the water environment. WH can be nurtured for wastewater treatment, and it can help with the procedure of water purification either for industrial wastewater or sewer water, in addition to other available techniques. The root structures of WH provide a suitable environment for aerobic bacteria to remove various impurities present in wastewater [11].

Giant Salvinia is an invasive aquatic weed and free-floating plant. However, due to the temperate climate, Malaysia is more susceptible to Salvinia infestation. Giant Salvinia varies in color from green to gold to brown. It is an aquatic fern with floating and oblong leaves, in which the leaves of young plants lie flat on the water surface. In contrast, the leaves of matured plants grow between 1.3 to $4.0 \mathrm{~m}$. A long chain formation occurs as the plants grow together to form mats. Giant Salvinia is very prolific and, under favorable conditions, can double the size of its mats in 7 to 10 days. As the mats continue to grow, they form thick layers of vegetation. Also, the surface of the Salvinia leaf has rows of cylindrical "hairs" topped with four branches that are joined at the tips to form a cage or eggbeater shape. These hairs give an elegant appearance and repel water. In matured plants, underwater rootlike structures conceal stalks that can have egg-shaped spore cases attached. In the United States, these spore cases are not known to contain fertile spores. This weed overwinters and reproduces vegetatively.

\section{Materials and Methods}

\subsection{Analytical methods and water quality parameters.}

Water quality parameters such as $\mathrm{pH}$, color, turbidity, nitrate, total phosphorous, and ammonia of the wastewater samples were analyzed according to standard methods for the examination of water and wastewater [12]. 


\section{Results and Discussion}

\subsection{Color.}

The outcome presented in Figure 1 shows that all the plants have a significant effect on the treatment of the wastewater samples. The color $(\mathrm{Pt}-\mathrm{Co})$ of the wastewater was reduced. However, based on the average performance of the vegetation, the giant Salvania plant is the best color reducing plant. The plant reduced almost $90 \%$ of the color, which outperforms all other species.

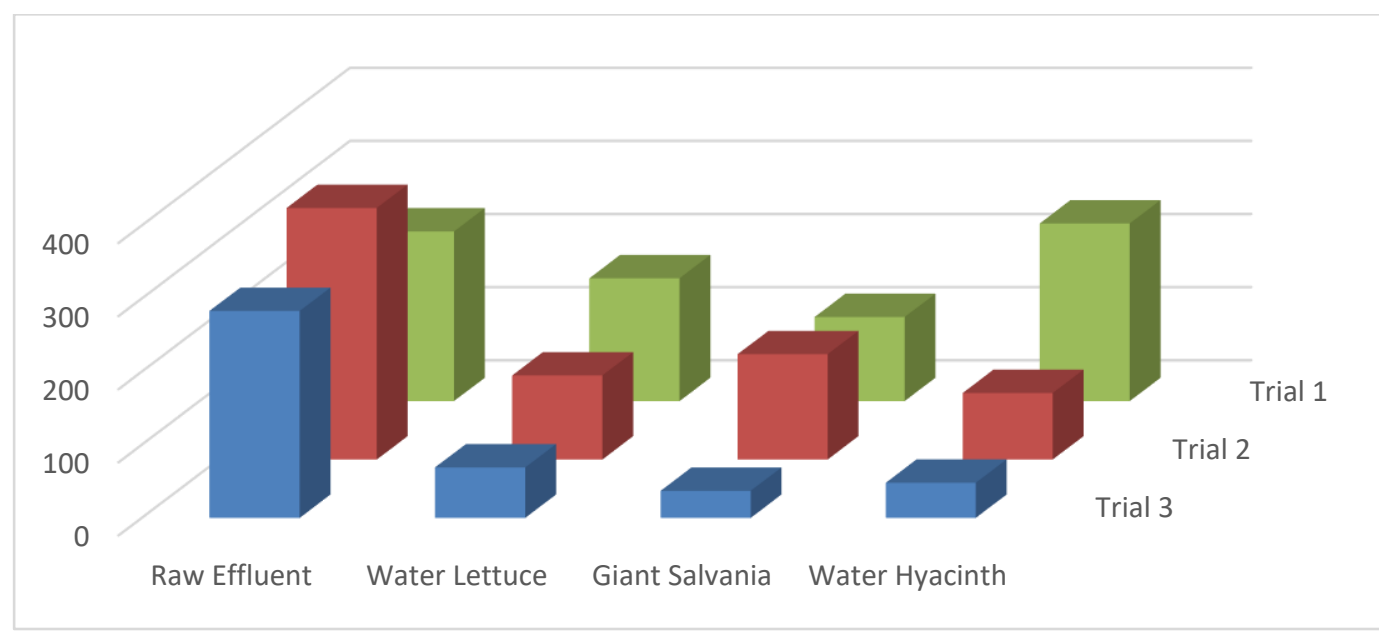

Figure 1. Analysis of color concentration.

\section{2. $p H$.}

As per Figure 2, the $\mathrm{pH}$ level has insignificant changes, while the water hyacinth was observed to produce an acidic effect on the wastewater. According to the results, we can see that all sample from the plant shows a reduction of $\mathrm{pH}$ value. However, according to the Department of Environment (DOE), class IIA water has a range of $\mathrm{pH}$ values between 6-9, which is still a safe $\mathrm{pH}$ to be released into the environment [13].

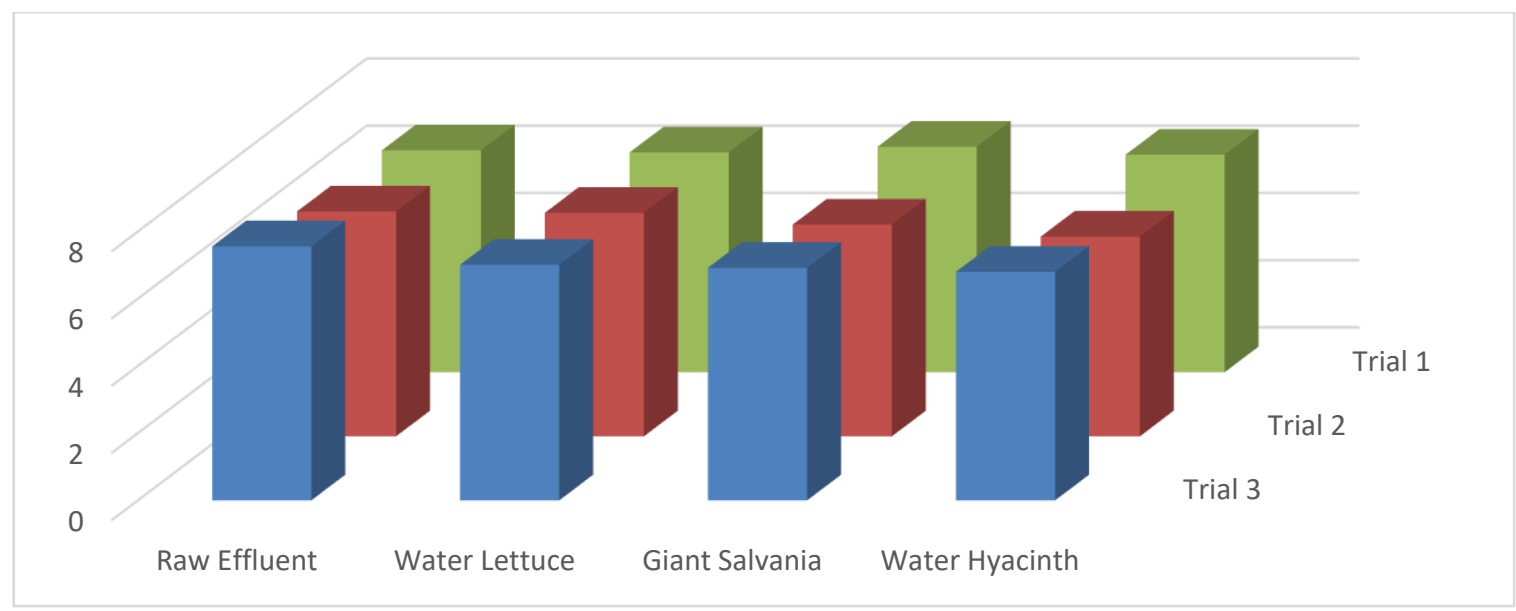

Figure 2. Analysis of $\mathrm{pH}$ concentration.

\subsection{Turbidity.}

Turbidity (NTU) results show that the vegetations perform well at reducing the turbidity level, as presented in Figure 3. On average, all vegetation species perform well, particularly 
the water hyacinth. The water hyacinth plant was capable of lessening the turbidity level due to the roots. The water hyacinth plant roots are long, and it almost reaches the bottom part of the tank. Additionally, the sedimentary roots from the plant also add as an element of turbidity absorption. When collecting the sample for testing; some of the sedimentary roots got into the sample container. The sample collection for the other plants does not have any plant sediments. An outlier from trial 1 water hyacinth sample shows a high reading, which might be caused by pests that lived in the tank. However, in the next sample collection (trial 2), there was no pests presence. The pests have the characteristics of a tadpole.

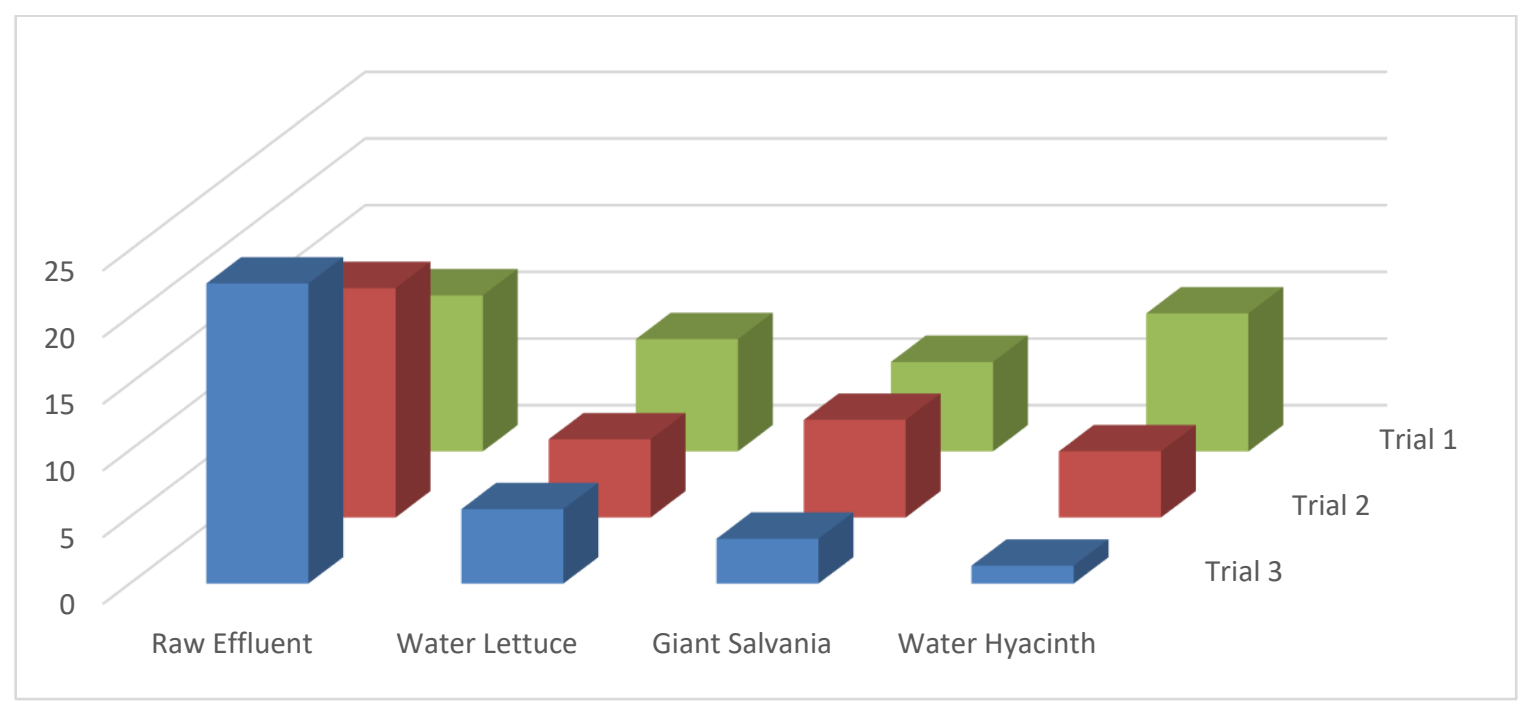

Figure 3. Analysis of turbidity concentration.

\subsection{Total phosphorous.}

The results obtained from the phosphorous analysis are presented in Figure $4(\mathrm{mg} / \mathrm{l})$. This shows that vegetation has a positive effect on the wastewater samples. Giant Salvinia plant demonstrated the best result in the removal of the total phosphorous content from the wastewater. It removed almost $95 \%$ of the phosphorous content.

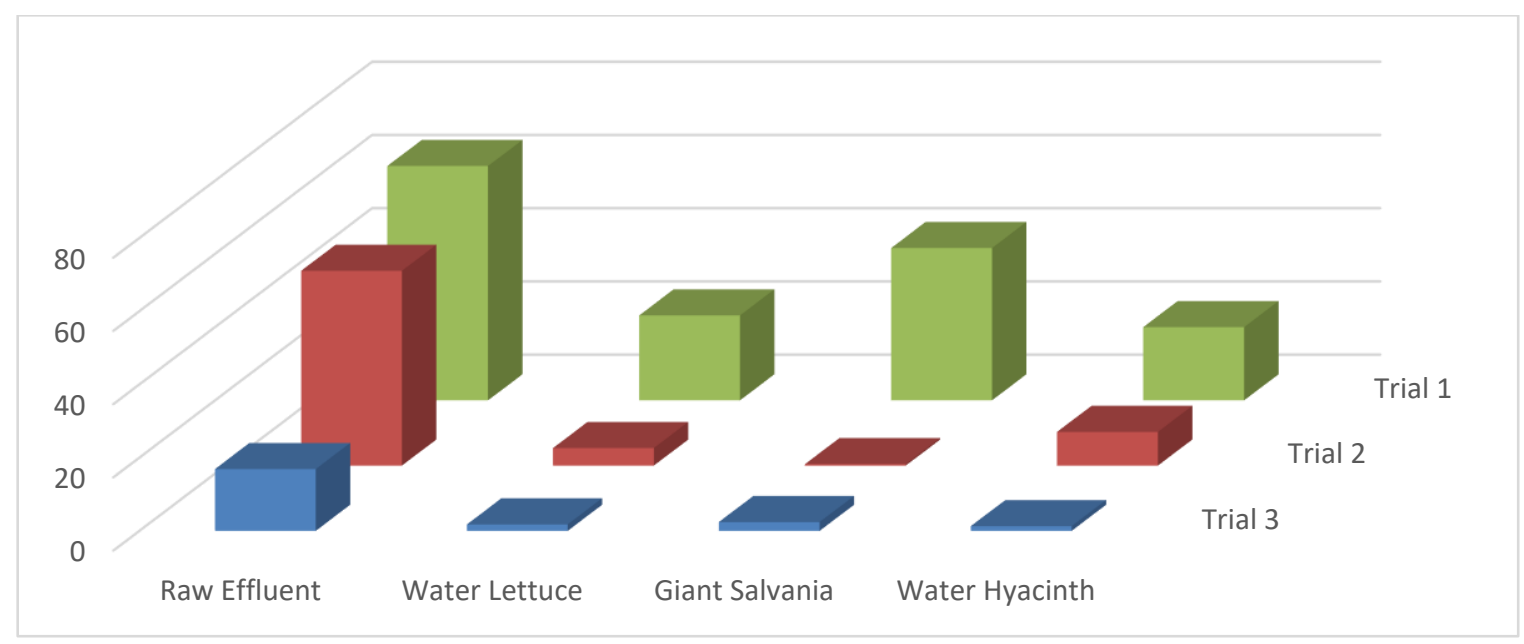

Figure 4. Analysis of total phosphorous concentration. 


\subsection{Nitrate.}

Figure 5 shows that the nitrate $(\mathrm{mg} / \mathrm{l})$ readings decreased after the treatment. Based on the graph, we can conclude that water lettuce indicated a great response to nitrate absorption. Almost $90 \%$ removal was recorded in one of the tests when the raw effluent contains a very high nitrate content.

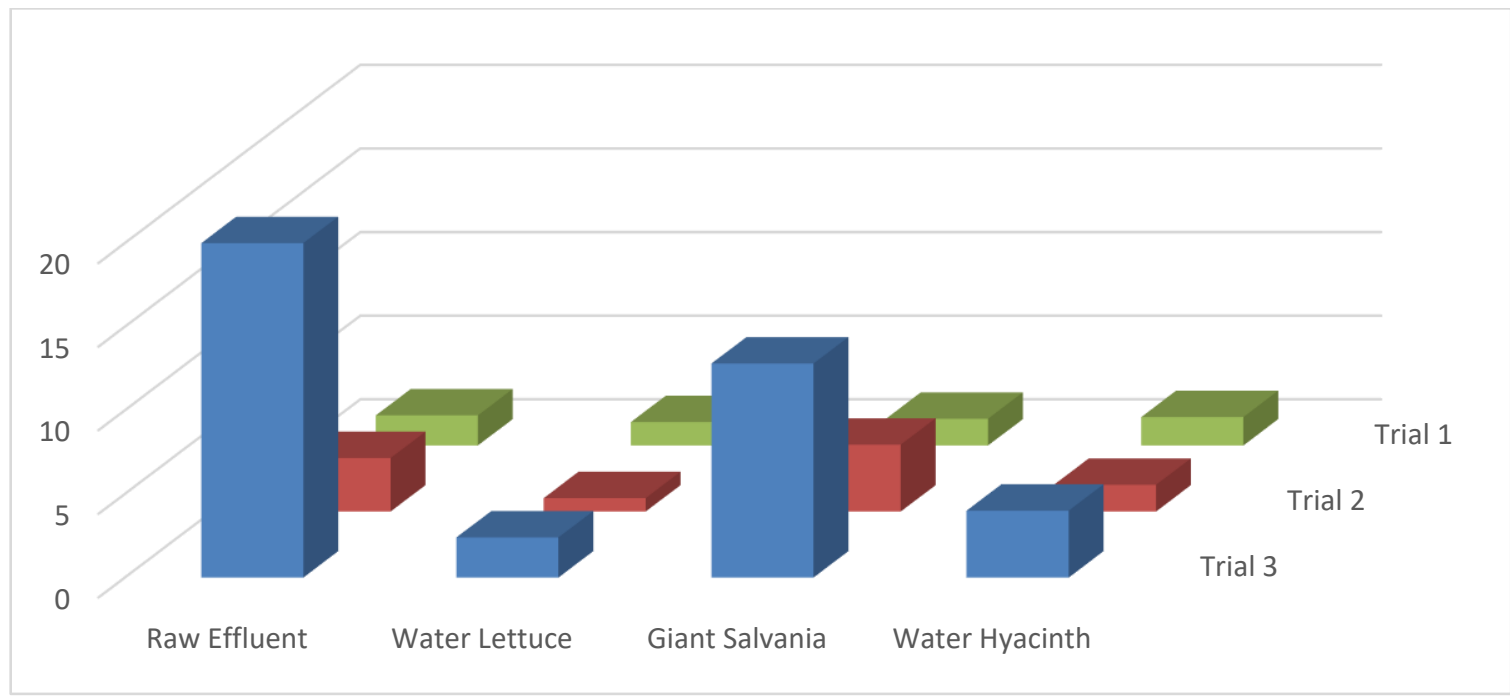

Figure 5. Analysis of nitrate concentration.

\subsection{Ammonia.}

Finally, the results presented in Figure 6 for ammonia (mg/l) show good performance. The vegetations reduced the ammonia in a similar pattern. Also, the presence of ammonia in the wastewater enhanced the growth of the vegetation.

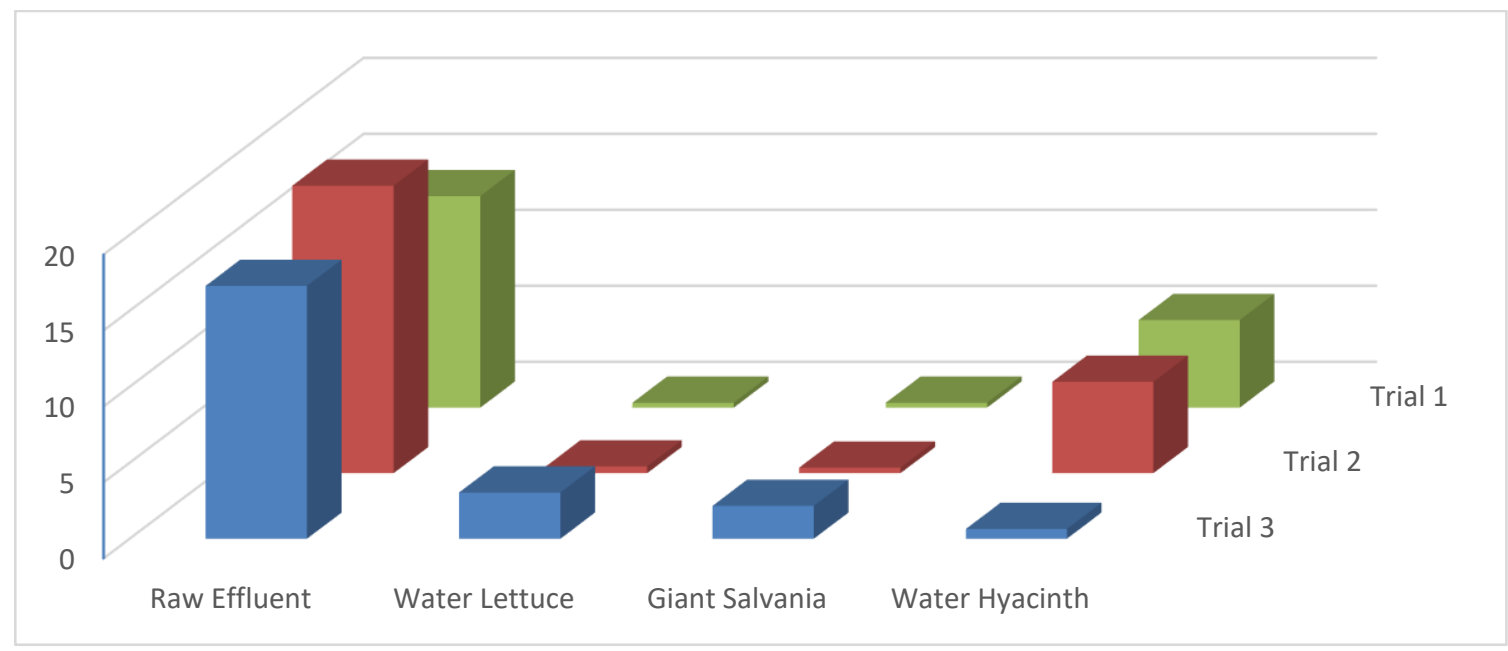

Figure 6. Analysis of nitrate concentration.

\section{Conclusions}

Biofiltration using water lettuce, water hyacinth, and giant Salvinia is an excellent alternative in the tertiary treatment of wastewater. The objective of the study was met due to the improvements in the quality of the wastewater. The wastewater effluent was much cleaner, with a significant reduction of turbidity and color. While $\mathrm{pH}$ has no significant change (or even marginally), the wastewater effluent's $\mathrm{pH}$ was classified as safe even before the treatment 
process. However, the reduction of turbidity, nitrate, phosphorous, and ammonia using the biofiltration techniques yielded a positive result. The vegetations used were capable of absorbing the nutrients within the stipulated period, yielding an average of over $50 \%$ removal of the nutrient traces in the raw effluent.

\section{Funding}

This research was funded by Universiti Tenaga Nasional (UNITEN) under the BOLD2020 grants.

\section{Acknowledgments}

\section{The authors would like to acknowledge Universiti Tenaga Nasional (UNITEN).}

\section{Conflicts of Interest}

The authors declare no conflict of interest.

\section{References}

1. Edmondson, V.; Cerny, M.; Lim, M.; Gledson, B.; Lockley, S.; Woodward, J. A smart sewer asset information model to enable an 'Internet of Things' for operational wastewater management. Autom. Constr. 2018, 91, 193-205, https://doi.org/10.1016/j.autcon.2018.03.003.

2. Olguín, E.J.; García-López, D.A.; González-Portela, R.E.; Sánchez-Galván, G. Year-round phytofiltration lagoon assessment using Pistia stratiotes within a pilot-plant scale biorefinery. Sci. Total Environ. 2017, 592, 326-333, https://doi.org/10.1016/J.SCITOTENV.2017.03.067.

3. Mustafa, H.M; Hayder, G; Jagaba, A.H. Microalgae: A Renewable Source for Wastewater Treatment and Feedstock Supply for Biofuel Generation. Biointerface Res. in Appl. Chem. 2021, 11, 7431-7444, https://doi.org/10.33263/BRIAC111.74317444.

4. Mustafa, H.M.; Hayder, G. Recent studies on applications of aquatic weed plants in phytoremediation of wastewater. A review article. Ain Shams Eng. J. 2020, https://doi:10.1016/j.asej.2020.05.009.

5. Pavithra, M.; Kousar, H. Potential of Salvinia molesta for Removal of Sodium in Textile Wastewater. J. Bioremediation Biodegrad. 2016, 7, https://doi.org/10.4172/2155-6199.1000364.

6. Hazmi, N.I.; Hanafiah, M. Phytoremediation Of Livestock Wastewater Using Azolla filiculoides and Lemna minor. Environ. Ecosyst. Sci. 2018, 2, 13-16, https://doi.org/10.26480/ees.01.2018.13.16.

7. Ariffin, F.D.; Abdul Halim, A.; Mohd Hanafiah, M.; Ramlee, N.A. Kebolehupayaan Fitoremediasi oleh Azolla pinnata dalam Merawat Air Sisa Akuakultur. Sains Malaysiana 2019, 48, 281-289, https://doi.org/10.17576/jsm-2019-4802-03.

8. Shah, M.; Hashmi, H.N.; Ghumman, A.R.; Zeeshan, M. Performance assessment of aquatic macrophytes for treatment of municipal wastewater. J. South African Inst. Civ. Eng. 2015, 57, 18-25, https://doi.org/10.17159/2309-8775/2015/v57n3a3.

9. Lu, Q.; He, Z.L.; Graetz, D.A.; Stoffella, P.J.; Yang, X. Uptake and distribution of metals by water lettuce (Pistia stratiotes L.). Environ. Sci. Pollut. Res. 2011, 18, 978-986, https://doi.org/10.1007/s11356-011-04530 .

10. Neuenschwander, P.; Julien, M.H.; Center, T.D.; Hill, M.P. Pistia stratiotes L. (Araceae). In: Biological Control of Tropical Weeds Using Arthropods. Muniappan, R.; Reddy, G.V.P.; Raman, A. Eds.; Cambridge University Press: Cambridge, 2009; pp. 332-352, https://doi.org/10.1017/CBO9780511576348.017.

11. Magar, R.B.; Khan, A.N.; Honnutagi, A. Waste Water Treatment using Water Hyacinth WasteWater Treatment using Water Hyacinth. 32ndIndian Eng. Congr. Inst. Eng. 2017, 2-5.

12. APHA Standard Methods; 21st ed.; American Public Health Association, Washington, 2005

13. Department of Environment (DOE), Environmental Quality Report, 2002-2005, Malaysia; Ministry of Science, Technology and Environment: Putrajaya, 2005. 